\title{
Skin impressions of Tehuelchesaurus (Sauropoda) from the Upper Jurassic of Patagonia
}

\author{
Olga del Valle GIMÉNEZ \\ Facultad de Ciencias Naturales, Universidad Nacional de La Patagonia «San Juan Bosco», \\ Ciudad Universitaria Km 4, (9000) Comodoro Rivadavia, Chubut, Argentina; \\ e-mail: ogimenez@unpata.edu.ar
}

\begin{abstract}
Most of the postcranial skeleton of the sauropod dinosaur, Tehuelchesaurus benitezii, collected from the Cañadón Calcáreo Formation (Upper Jurassic) in the Chubut River valley, includes several fragments of skin impressions, which correspond to different parts of the body, such as portions of forelimbs, scapular and thorax regions. The most representative skin samples (Type I) consist of non-overlapping tubercular scales of hexagonal shape ( $3 \mathrm{~cm}$ long - 2,4 cm width), alternating with smaller ones $(2 \mathrm{~cm}$ long - 1,5 cm width) disposed in a rosette pattern. Other scale samples (Type II) are similar to the first ones, but smaller in size, displaying rhomboidal shapes disposed also in a rosette pattern. This discovery means an unique opportunity to improve the knowledge of the external aspect of non-avian dinosaurs.
\end{abstract}

Key words: Sauropod, Skin, Jurassic, Chubut, Argentina.

Articulated sauropods skeletons from continents that were once part of Gondwana are not common. Accordingly, the discovery of a partial skeleton of Tehuelchesaurus benitezii Rich et al. (1999) in the western Chubut Province, Argentina, is of particular interest. This specimen belongs without doubt, to a single individual, and much of it was found in articulation. Unfortunately, it was found without the skull, but includes dorsal, sacral and caudal vertebrae, parts of both fore and hind limbs, parts of scapular girdles and pelvic, few rib fragments, and skin impressions from different parts of the body. The aim of this paper is to present a detailed description of the skin impressions of the Tehuelchesaurus benitezii.

\section{History of discovery}

The first discovery of dinosaur skin impressions corresponds to a $20 \mathrm{~cm}$ diameter patch directly overlapping on a forelimb of the sauropod Pelorosaurus (Mantell, 1852), from the Jurassic of England. This skin impression consisted of non-overlapping scales tubercles, arranged in rosette-pattern. The largest sample of skin impressions associated to sauropods bones was discovered by Barnum Brown (1935) at the Howe Quarry (Wyoming, USA). Unfortunately, most of the impressions were lost during the excavation to recover the bones. Recently, numerous skin impressions and many dermal spines have been referred to diplodocid sauropods, that presumably were alined from the neck going down to the tail (Czerkas, 1992, 1994). There are numer- ous discoveries of the Titanosauria in which bone plates are associated with the skeleton found. The most particular one was the Saltasaurus loricatus (Bonaparte \& Powell, 1980) which has bony scutes surrounded by small ossicles, suggesting that some sauropods were armored. More recently in NW Patagonia several impressions of embryonic skin were found within numerous titanosaur sauropod eggs (Chiappe et al., 1998). Discoveries of sedimental skin impressions of Jurassic sauropods are very scarce throughout the world. This is the first notice about the skin of these megaherbivorous in South America.

Abbreviations. MPEF-PV: Museo Paleontológico «Egidio Feruglio», Chubut, Argentina; PVL: Fundación Miguel Lillo, Tucumán, Argentina; MCF-PVPH: Museo Carmen de Funes, Paleontología de Vertebrados, Plaza Huincul, provincia del Neuquén, Argentina.

\section{MATERIALS AND METHODS}

The materials described here correspond to a variety of skin fragments associated to the holotype specimen of Tehuelchesaurus benitezii (MPEF-PV 1125) collected during the summer of 1994-1995.

Original location. The holopype of Tehuelchesaurus benitezii Rich et al. (1999), was collected at $43^{\circ} 10^{\prime} 3^{\prime \prime} \mathrm{S}-69^{\circ} 15^{\prime} 00^{\prime \prime} \mathrm{W}$ (World Geodesic System, 1984) on Estancia Fernández, Chubut, Patagonia, Argentina (Fig. 1). 

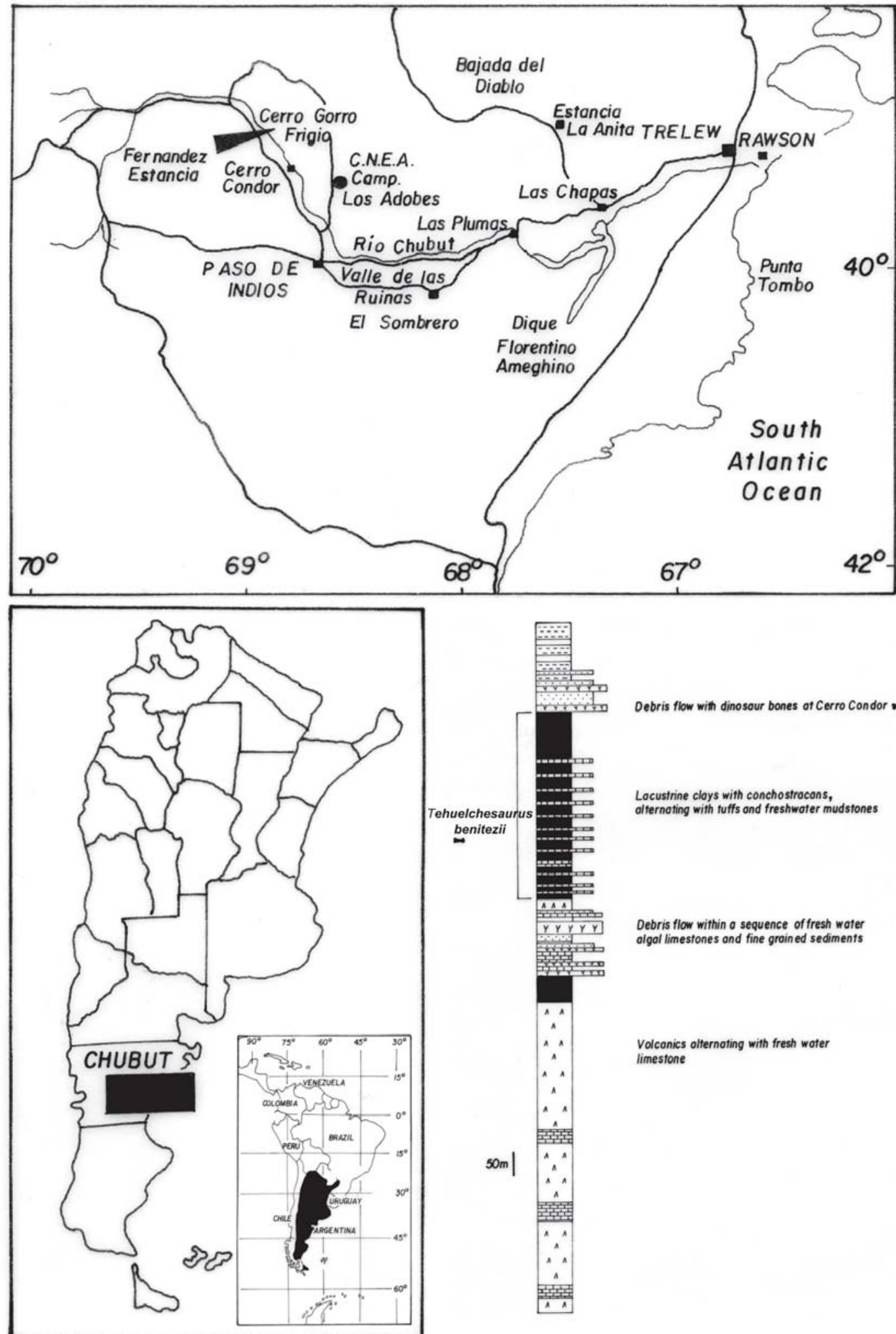

Debris flow with dinosour bones at Cerro Condor $\mathrm{m}$

Locustrine cloys with conchostrocons,

alternoting with fuffs ond freshwoter mudstones

Debris flow within a sequence of fresh woter olgol limestones and fine groined sediments limestone

Fig. 1. Geographic location and stratigraphic section through the Cañadón Calcáreo Formation, showing the location of Tehuelchesaurus benitezii at Estancia Fernandez, Chubut, Argentina. To Rich et al. (1999). 


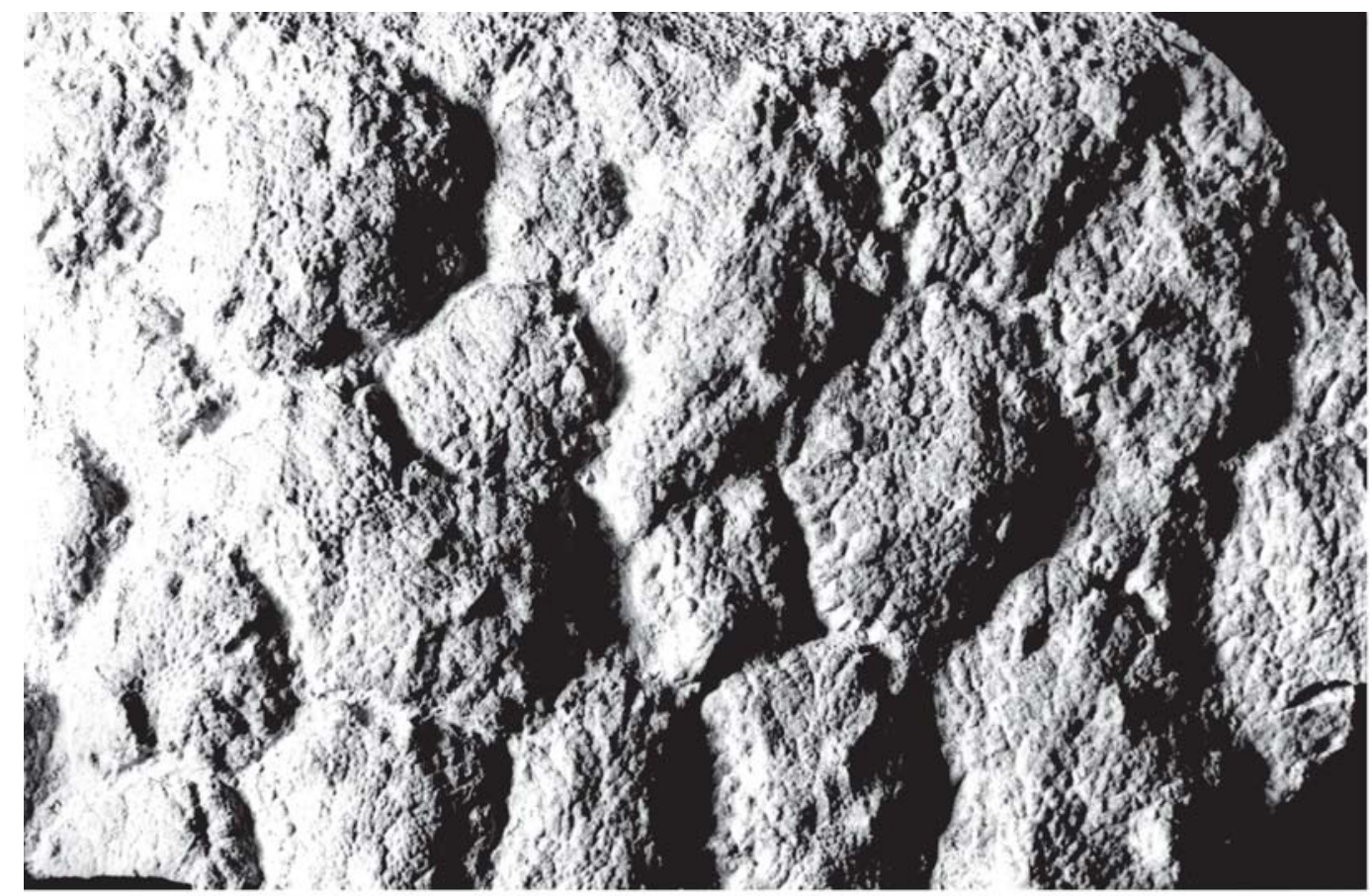

Fig. 2. Skin impressions of Tehuelchesaurus benitezii. Skin patch Type I, showing a large tuberculated scales MEF-PV 1125/1. Scale bar: $1 \mathrm{~cm}$.

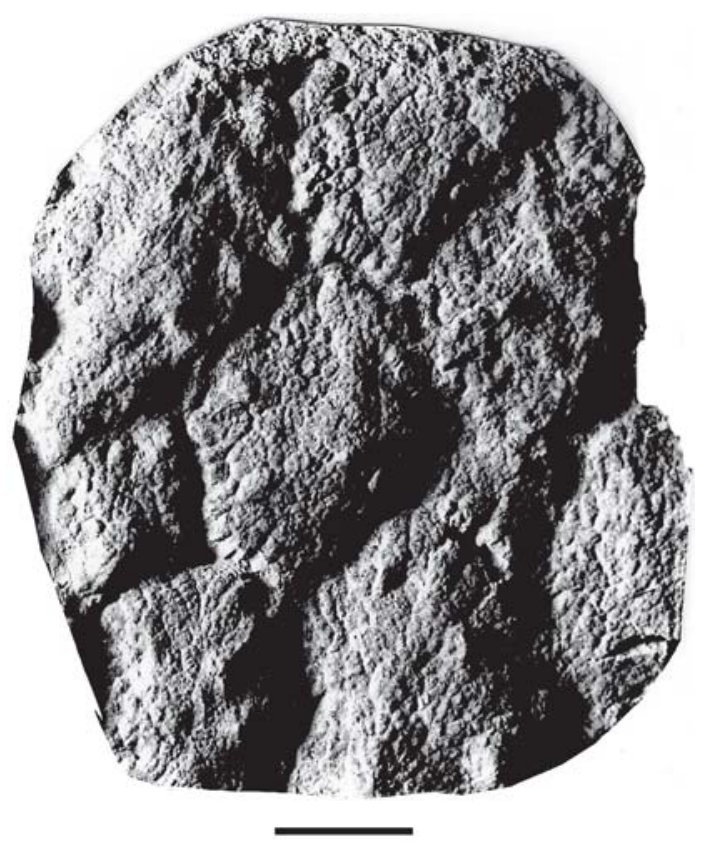

Fig. 3. Detail of rosette structure of skin patch (Type I) MEF-PV 1125/1. Scale bar: $1 \mathrm{~cm}$.
Stratigraphy. Traditionally, all the MiddleUpper Jurassic sediments of the Cañadón Asfalto basins have been grouped together in the Cañadón Asfalto Formation, although two different sequences have been recognized (Figari \& Courtade, 1993; Page et al., 1999). Whereas the lower sequence (Cañadón Asfalto sensu stricto) is mainly composed of lacustrine shales, limestone and marls, with rare intercalations of conglomerates and sandstones, the upper one starts with lacustrine shales, but is later dominated by fluvial and overbank deposits. Furthermore, both sequences also differ significantly in their tectonic structure and age. Thus, it might be justified to distinguish an Upper Jurassic (Kimmeridgian-Tithonian) Cañadón Calcáreo Formation from the Middle Jurassic (Callovian) Cañadón Asfalto Formation, as proposed by Proserpio (1987). Although Tehuelchesaurus (Rich et al., 1999), was originally attributed to the Cañadón Asfalto Formation (Middle - Upper Jurassic), at present, its stratigraphical occurrence has been proposed for the overlying Cañadón Calcáreo Formation (Rauhut, 2003).

The rocks containing bones and skin impressions of Tehuelchesaurus benitezii (Fig. 1) are 


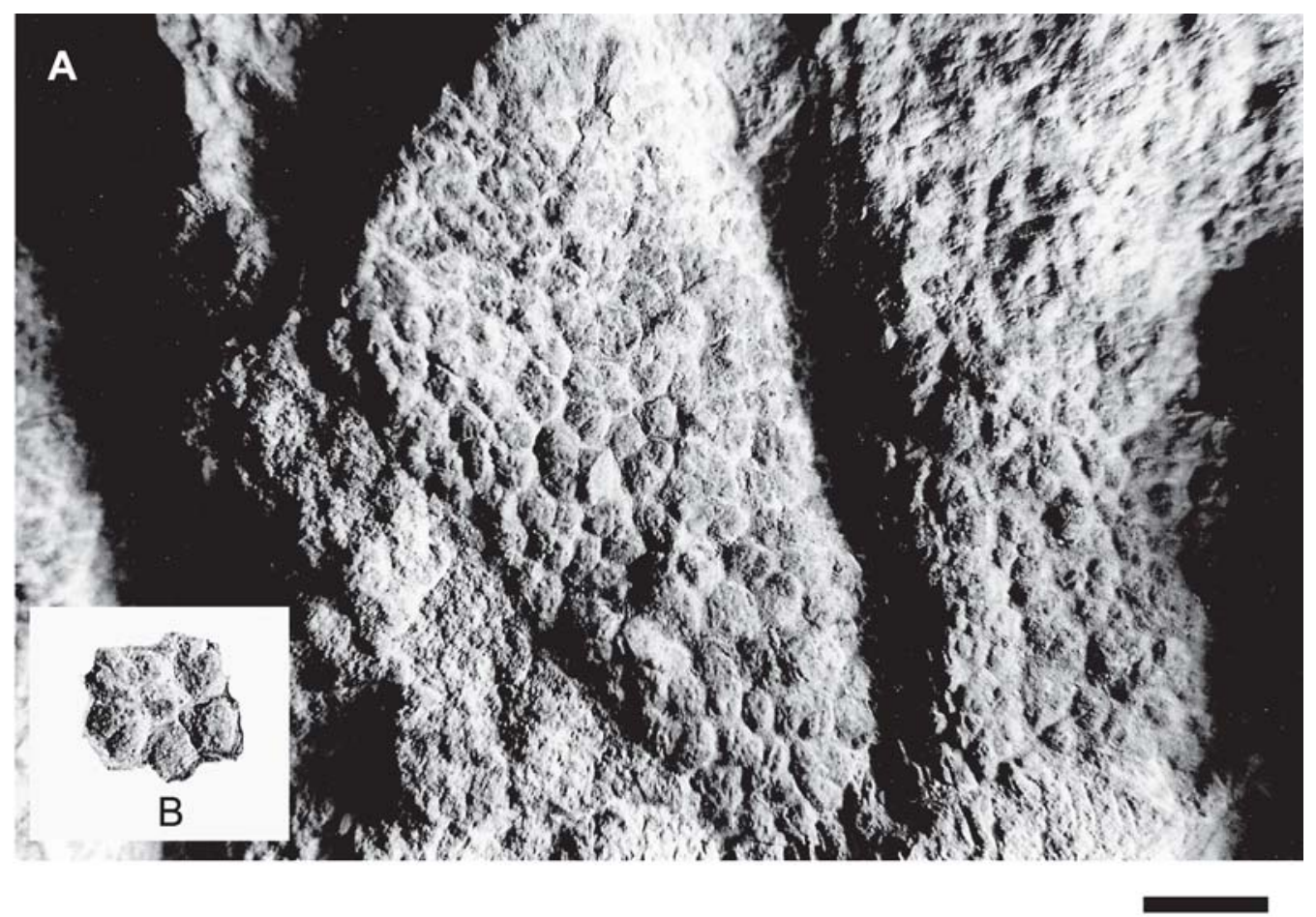

Fig. 4. Skin impressions of Tehuelchesaurus benitezii. A. Skin patch (Type II) MEF-PV 1125/3. B. Small tuberculated scales. Scale bar: $1 \mathrm{~cm}$.

fine, light green tuffs. Conchostracean and plant impressions are present in the bone-bearing unit. The well-preserved plant remains suggest a nearly autochthonous taphocoenosis (Rich et al., 1999).

\section{DESCRIPTION OF THE EPIDERMAL IMPRESSIONS}

In the epidermal impressions of Tehuelchesaurus benitezii no evidence of the existence of bony plates, thus indicating that these sauropods were no armoured. The term tubercle must be interpretated as non-overlapping scales adopting the terminology proposed by Gavrilov (1958).

In all parts of the body where the epidermal impressions are preserved, the skin consists of tuberculate non-overlapping scales radiating in a rosette pattern. The size of individual tubercles is determined by the size of the scales. A basic ground plan consists of the smaller scales were found on the underside of the animal. Larger tubercles scales were found on the animal's outer surface.

The available fragments of skin impressions of Tehuelchesaurus correspond to different parts of the body. One of the fragments (natural cast of the integument and its counterpart) from the thoracic region is associated with a rib fragment MPEF-PV 1125/3 (Fig. 4) and another fragments were found in association to the left humerus MEF-PV1125/4. The largest specimen collected MPEF-PV 1125/ 1 (see Fig. 2) measures $25 \mathrm{~cm}$ by $40 \mathrm{~cm}$ and was associated to the left scapular blade, which suffered a post mortem displacement. Two other fragments were found in association with dorsal vertebrae MEF-PV 1125/5/6. An isolated patch of integument, not associated to any specific part of the body, is preserved as a positive print and its negative counterpart MPEF-PV 1125/2. The morphology of the integument shows polygonal tubercled scales. Although dermal spines have been reported for diplodocids sauropods (Czerkas 1992, 1994, 1997), our specimen shows no evidence of these structures.

Types of skin patterns. Type I. The largest available skin impression MEF-PV 1125/1, associated to a scapular blade, reveals that the skin was arranged in rosette patterns formed with almost smooth, hexagonal in outline, large tubercle scales $(2,5 \mathrm{~cm}$ by $3 \mathrm{~cm})$ alternating with smaller tubercles ( $2 \mathrm{~cm}$ by $1,5 \mathrm{~cm}$ ), (Fig 2 ). A rosette pattern of scales is present in MEF-PV1125/ 1-6 1125/1-6 (Fig. 3). The hexagonal central scale is surrounded by six scales. Five of them has 


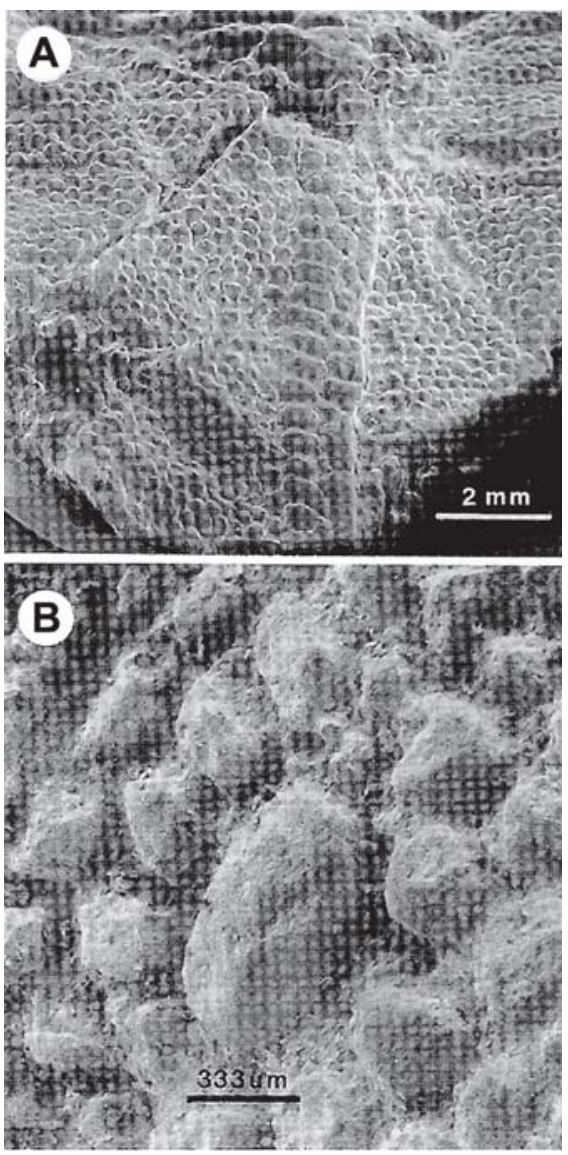

Fig. 5. Natural cast of the integument of the sauropod embryons from Auca Mahuevo. A. Large patch (PVH126). B. Detail of rosette structure of PVPH-130. (Adopted from Chiappe et al., 1998).

nearly the same diameter of the central one, and the other displays the central scale's diameter.

Type II. Very small tubercles, varying from 1 to $3 \mathrm{~mm}$ in diameter and 2 to $4 \mathrm{~mm}$ long, being romboidal in outline, not imbricated, showing a rosette-like pattern (Fig.4). One fragment of minute tubercles corresponds to the thoracic region MEF-PV 1125/3, and two fragments to the arm MEF-PV 1125/4.

Comparisons. The natural cast of Tehuelchesaurus were confronted to those of other sauropods, including the forelimb of the Pelorosaurus (Mantell, 1852), from the neck, and the belly region at diplodocid sauropods (Czerkas, 1992, 1994); as well with the skin of embryos of Titanosauria (Chiappe et al., 1998) MCF-PVPH126. In the case of materials housed abroad, the bibliographical information has been the main data source.
In general, the skin of Tehuelchesaurus is similar to other non-avian dinosaurs, showing non-overlapping scales, polygonal in outline (hexagonal), arranged in a rosette pattern (Giménez, 2000) and no armored. Nevertheless, the Tehuelchesaurus skin is more similar to Pelorosaurus and diplodocid sauropods than to the embryos of Auca Mahuevo, in which each rosette is formed by a hexagonal central scale surrounded by other six. Besides in the three taxons the external surface of each of the scales (Type I) presents delicate smooth bumps, which were interpretated as delicate eculturations which are the result of the contact between dermis and epidermis (Hooley 1917; Czerkas, 1992, 1994, 1996). The tegumentary impressions of Tehuelchesaurus are different from those of the embryos from the Auca Mahuevo MCF-PVPH-126, the circular, central scale is surrounded by 10 smaller scales that have roughly one-half the central scale's diameter (Fig. $5 \mathrm{a}, \mathrm{b}$ ). The scales are not polygonal, but rather circular and disposed adopting the shape of a daisy similar distribution of the osteoderms associated to the Titanosauria skeleton (Chiappe et al., 1998), including Saltasaurus loricatus (see Bonaparte \& Powell, 1980).

The tegumentary uniform morphology presented in the bigger skin fragments belonging to the embryos (Fig. 5a) constitutes another difference with the Tehuelchesaurus and Pelorosaurus in which type I and type II scales are recognized. Another difference is the presence of rectangular scales presented in three rows which belong to the dorsal region.

Some modern reptiles, such as chameleons and gekonids, have a tubercular integument morphology. Heloderma suspectum, the Gila Monster, presents tubercles over the head that are larger compared to the body size of the animal.

\section{CONCLUSIONS}

The interpretation of the tegumentary samples of Tehuelchesaurus, Pelorosaurus, diplodocids and embryos titanosaurs allows us to support a reptilian nature of the skin displaying tubercles scales, non-overlapping and a rosette pattern which differs in size according to the distinct parts of the body. The larger scales are from the dorsal region of the body and the smaller ones were found on the underside region.

\section{ACKNOWLEDGMENTS}

I thank to F. Novas and L. Salgado for their critical reading of the manuscript, to the staff of the Museo Paleontológico Egidio Feruglio for 
preparing and allowing to study the materials, to J. Rodríguez for assisting in the paleoenvironmental interpretations, to A. Blachaqis for making the figures and to E. Jones for the photographs.

\section{BIBLIOGRAPHY}

Bonaparte, J.F. \& J.E. Powell. 1980. A continental assemblage of tetrapods from the upper Cretaceous beds of El Brete, northwestern Argentina (Sauropods-Coelurosauria-Carnosauria-Aves). Mem. Soc. Geol. Fr. 39,19-28.

Brown, B. 1935. Sinclair dinosaur expedition, 1934. Natural History, 36: 3-15.

Czerkas, S.A. 1992. Discovery of dermal spines reveals a new look for sauropod dinosaurs. Geology, 20: 1068-1070.

- 1994 The history and interpretation of sauropod skin impressions. Gaia 10: 173-182.

- $\quad$ 1997. Skin. In P. J. Currie \& K. Padian (eds.), The Encyclopedia of Dinosaurs, pp. 669-675. Academic Press, San Diego, California, USA.

Chiappe, L.M., R.A. Coria, L. Dingus, F. Jackson, A. Chinsamy \& M. Fox. 1998. Sauropod dinosaur embryos from the Late Cretaceous of Patagonia. $\mathrm{Na}$ ture 396: 258-261.

Fígari, E.G. \& S.F. Courtade. 1993. Evolución Tectosedimentaria de la Cuenca de Cañadón Asfalto, Chubut, Argentina. $12^{\circ}$ Congreso Geológico Argentino y $2^{\circ}$ Congreso de Exploración de Hidrocarburos (Buenos Aires), Actas 1: 66-77.
Gavrilov, K. 1958. Curso de Anatomía y Fisiología Comparada (Tegumento). Universidad Nacional de Tucumán San Miguel de Tucumán. III: 125-196.

Giménez, O. 2000. The discovery of skin impressions of a sauropod dinosaur in Chubut province, Argentina. 60th Annual Meeting, Society of Vertebrate Paleontology Abstracts of Papers. Journal of Vertebrate Paleontology. 20 (3): 44A.

Hooley, R.W. 1917. On the integument of Iguanodon bernissartensis Boulenger, and of Morosaurus becklesii Mantel. Geol. Mag., (6) 4: 148-150.

Mantell, G.M. 1852. Proceedings of Royal Institution, 1 (untitled in citation by Hooley, 1917).

Page, R., A. Ardolino, R.E. de Barrio, M. Franchi, A. Lizuain, S. Page \& D. Silva Nieto. 1999. Estratigrafía del Jurásico y Cretácico del Macizo de Somún Curá, provincias de Río Negro y Chubut. In: R. Caminos (ed.), Geología Argentina, Subsecretaría de Minería de la Nación, Buenos Aires, PP.460-488.

Proserpio, C.A. 1987. Descripción geológica de la Hoja 44e, Valle General Racedo, provincia del Chubut. Dirección Nacional de Minería y Geología, Boletín 201:1-102.

Rich. T., P. Vickers-Rich, O. Giménez, R. Cúneo, P. Puerta \& R. Vacca. 1999. A new Sauropod dinosaur from Chubut Province, Argentina. Proccedings of the Second Gondwanan Dinosaur Symposium. National Museum Monographs 15:61-84, Tokyo.

Rauhut, O.W.M. 2003. A dentary of Patagosaurus (Sauropoda) from the Middle Jurassic of Patagonia. Ameghiniana 40 (3): 425-432.

Recibido: 3-IX-2006 Aceptado: 20-IX-2007 